\title{
TONSILLECTOMY IN THE PREVENTION AND TREATMENT OF RHEUMATISM.
}

BY

LEONARD FINDLAY, M.D., D.Sc., JAMES W. MACFARLANE, M.B., and MARY M. STEVENSON, M.A., M.D.

(From the Dept. of Pædiatrics, Glasgow University, and Royal Hospital for Sick Children, Glasgow.)

In the organized attack on the rheumatic infection there is probably no more debated point than that of the efficacy of tonsillectomy. As portals of entry of the virus the tonsils are supposed to occupy first place, and hence it is only natural that one of the commonest procedures in the attempt not only to prevent the disease but also to hinder its progress, should consist in their removal. It must be admitted, however, that so far as the latter purpose is concerned the operation savours of locking the stable after the steed has been stolen.

Statistics vary regarding the incidence of disease of the tonsils in examples of the rheumatic infection, but there is no doubt that in a goodly proportion of the patients abnormal tonsillar tissue is present and that a history of a previous tonsillitis is obtained. In a recent survey in London ${ }^{1}$ the incidence of diseased tonsils in rheumatic children was said to be roughly 60 per cent. as against 50 per cent. in non-rheumatic children, whereas in a simultaneous enquiry carried out in Glasgow only 45 per cent. of the rheumatic and 40 per cent. of the non-rheumatic presented tonsillar abnormality. Disease of the tonsils is thus so widespread, not only among the non-rheumatic members of the class of society which provides the majority of our examples of rheumatism, but as we all know among the children of the better classes as well, in whom on the other hand, rheumatic fever is admittedly rare, that it is exceedingly difficult to assess the importance of this condition in the pathogenesis of the infection. Nevertheless it seems rational to remove a possible focus of infection and portal of entry, apart altogether from the effect of the operation on the general health, and it has been our custom to have the tonsils enucleated in all exomples of the disease when there was any question of enlargement. The present communication is an analysis of our results in an attempt to appraise the value of this line of attack.

\section{EFFECT OF TONSILLECTOMY ON ARTHRITIS AND CHOREA.}

Much work has already been done in this direction and an enormous literature has grown round the question of tonsillectomy and its effects. At first the reports of the result of the operation were laudatory but latterly they have revealed much scepticism. Miller ${ }^{2}$, however, raises an interesting and possibly important point in the issue when he differentiates between chorea and arthritis in assessing the value of this operation, and in the analysis of our material we have followed his example. Thus in Table 1 arthritis and chorea have been classified separately so that the effect of the operation on these two manifestations may be contrasted. In addition, however, the effect on the rheumatic infection as a whole is shown by not differentiating between the 
types of manifestations (Table 2). The number of attacks include not only initial attacks but all recurrences as well.

It will be readily understood that to judge properly of the value of the operation of tonsillectomy it is essential that the cases be observed over a prolonged period and hence we have selected those cases which first came under our notice during the years 1922-1924 inclusive. The cases had been followed during the succeeding years and all were seen towards the end of 1928. This material comprises a total of 153 patients from which to draw conclusions. In contrasting the various groups it should be noted that all the patients were under observation for approximately the same length of time, namely, 5 to 8 years, and as the operation was performed in the great majority of the cases prior to 1925 , the pre- and post-tonsillectomized-observation periods are also approximately of the same duration.

TABLE 1.

SHOWING EFFECT OF TONSILLECTOMY ON ARTHRITIS AND ON CHOREA.

\begin{tabular}{|c|c|c|c|c|c|c|}
\hline \multirow[b]{2}{*}{ Group. } & \multicolumn{3}{|c|}{ Arthritis } & \multicolumn{3}{|c|}{ Chorea } \\
\hline & $\begin{array}{l}\text { No. of } \\
\text { cases. }\end{array}$ & $\begin{array}{l}\text { No. of } \\
\text { attacks. }\end{array}$ & $\begin{array}{l}\text { No. per } \\
\text { person. }\end{array}$ & $\begin{array}{l}\text { No. of } \\
\text { cases. }\end{array}$ & $\begin{array}{c}\text { No. of } \\
\text { attacks. }\end{array}$ & $\begin{array}{l}\text { No. per } \\
\text { person. }\end{array}$ \\
\hline Tonsillectomized before first attack & 3 & 5 & $1 \cdot 7$ & 7 & 21 & $3 \cdot 0$ \\
\hline $\begin{array}{l}\text { Not tonsillectomized. } \\
\qquad \begin{array}{l}\text { (a) Requiring tonsillectomy ... } \\
\text { (b) Not requiing tonsillectomy } \\
\text { Total ... }\end{array}\end{array}$ & $\begin{array}{l}36 \\
32 \\
68\end{array}$ & \begin{tabular}{|r|}
49 \\
51 \\
100
\end{tabular} & $\begin{array}{l}1 \cdot 3 \\
1 \cdot 6 \\
1 \cdot 5\end{array}$ & $\begin{array}{l}16 \\
19 \\
35\end{array}$ & $\begin{array}{l}12 \\
34 \\
46\end{array}$ & $\begin{array}{l}0 \cdot 7 \\
1 \cdot 8 \\
1 \cdot 3\end{array}$ \\
\hline $\begin{array}{cccc}\text { Tonsillectomized during observation } \\
\text { Before } & \ldots & \ldots & \ldots \\
\text { After } \ldots & \ldots & \ldots & \ldots\end{array}$ & 27 & $\begin{array}{r}32 \\
7\end{array}$ & $\left.\begin{array}{r}1 \cdot 2 \\
\cdot 2\end{array}\right\} 1 \cdot 4$ & 24 & $\begin{array}{r}33 \\
6\end{array}$ & $\left.\begin{array}{c}1 \cdot 3 \\
\cdot 66\end{array}\right\}^{1.96}$ \\
\hline
\end{tabular}

In Table 1 perhaps the most striking feature is the smallness of the group of cases developing arthritis after a preliminary tonsillectomy. This fact is particularly arresting when one appreciates that of the total 153 cases investigated patients with arthritis were half again as numerous as those with chorea numbering as they did 90 and 63 respectively. At first sight this altered proportion of arthritis to chorea might seem to give some support to Miller's contention that tonsillectomy has a greater prophylactic effect on arthricis than on ehorea, if it has any prophylactic effect at all, yet a survey of the state of matters which prevailed in the non-tonsillectomized children reveals a less incidence of attacks per person of both chorea and arthritis and among these a greater incidence in those who did not require tonsillectomy. Hence one feels rather dubious about drawing any conclusions. The same points too emerge from the analysis of all the cases when no differentiation is made between the types of the rheumatic manifestation, viz:-a greater incidence of manifestations per person among the tonsillectomized than the non-tonsitlectomized and among the latter a greater incidence in those not requiring the operation than in those who did (Table 2 ): 
TABLE 2.

EFFeCt of tonsillectomy on RHEUMATIC MANifESTATIONS.

\begin{tabular}{|c|c|c|c|c|c|c|}
\hline & & & & $\begin{array}{l}\text { No. of } \\
\text { cases. }\end{array}$ & $\begin{array}{l}\text { No. of } \\
\text { attacks. }\end{array}$ & $\begin{array}{l}\text { No. per } \\
\text { person. }\end{array}$ \\
\hline 'Tonsillectomized before first attack & $\ldots$ & $\ldots$ & $\ldots$ & 8 & 21 & $2 \cdot 6$ \\
\hline \multirow[t]{2}{*}{$\begin{array}{l}\text { Not tonsillectomized. } \\
\text { (a) Requiring tonsillectomy } \\
\text { (b) Not requiring tonsillectomy }\end{array}$} & $\begin{array}{l}\cdots \\
\cdots\end{array}$ & $\begin{array}{l}\cdots \\
\cdots\end{array}$ & $\begin{array}{l}\cdots \\
\cdots\end{array}$ & $\begin{array}{l}45 \\
42\end{array}$ & $\begin{array}{l}82 \\
82\end{array}$ & $\begin{array}{l}1 \cdot 8 \\
1 \cdot 9\end{array}$ \\
\hline & & \multicolumn{2}{|c|}{ Total } & 87 & 164 & $1 \cdot 8$ \\
\hline
\end{tabular}

It may be, of course, that of children the subjects of a preliminary tonsillectomy it is only the specially susceptible who will succumb, and in them recurrences would naturally tend to be more numerous. This hypothesis gains support from the behaviour of the rare examples of the disease in the better class child, who from the family history would seem specially susceptible and who, in spite of extreme care and living under ideal conditions, runs through the whole gamut of the malady within a comparatively short time.

In Table 1 are also detailed the number of attacks for the periods before and after the operation in these cases submitted to tonsillectomy during the course of the infection. As the ante- and post-operation periods are on the whole shorter-on the average only one half of the total period of the disease observed-one would not expect the same case incidence. Moreover, as there would always be a greater number of 1st attacks then 2 nd attacks, and 2nd attacks than 3rd attacks and so on, and as the tonsillectomy was always performed after the disease had disclosed itself by the presence of one or more attacks, there would be a natural tendency for the case incidence to be less high during the post-operation than during the pre-operation period. This is in fact what was found. The figures do show, however, that there was a greater fall during the post-operation period in the incidence of arthritis than of chorea, but it is very questionable if any conclusions can be drawn from this difference since the sum of attacks, at least in arthritis, during the two periods--anteand post-operation-practically equals the incidence found during the whole course of the illness in the non-tonsillectomized patients.

Thus though a preliminary tonsillectomy may possibly render an individual less susceptible to arthritis, our results do not lend any support to the idea that an intercurrent tonsillectomy prevents recurrences of either arthritis or chorea. In this connection it is worth remembering, however, that as cardiac disease is more likely to follow arthritis than chorea, any benefit of a preliminary tonsillectomy in preventing arthritis will assume an added value.

\section{EFFeCT OF TONSILLECTOMY ON THE DEVELOPMENT OF CARDIAC DISEASE.}

Even supposing, however, that tonsillectomy does not make an individual less susceptible to arthritis or chorea, is it possible that it might render less 
probable implication of the heart? This is a statement which has indeed been made by several writers, e.g., Kaiser ${ }^{3}$ and Miller ${ }^{2}$.

In a study of this question we have come to the conclusion that it is important to distinguish between an initial or preliminary tonsillectomy and one performed during the course of the illness, since on the particular stage of the disease depends the probable development or otherwise of disease of the heart. There would seem to prevail a certain amount of doubt regarding the period in the course of the disease at which carditis is most probable, and whether or not recurring arthritis or chorea renders an individual more liable to this complication. In order to obtain evidence on this point it is essential that the complete history of the infection be known so that the cardiac implication can be related to a particular rheumatic attack. Any case coming under observation with a cardiac lesion and having already passed through several attacks of chorea or arthritis is unsuitable for the purpose, but those patients who were seen with the first manifestation of the disease, or those with a history of one or more attacks, and with the heart still intact, are applicable. Of such suitable cases for analysis we have 108 .

In the following table (Table 3) where the cases are grouped according to whether there occurred in the one individual both chorea and arthritis, or only chorea or arthritis, the number of patients passing through one or more attacks and the percentage incidence of cardiac disease consequent on each attack are shown. It should be noted that the cases included in any succeeding subgroup are only those who had passed through a previous attack with the heart unscathed.

TABLE 3.

Showing the incidence of Cardiac disease developing in 1st, 2ND or 3Rd, etc., attack OF ARTHRITIS AND CHOREA.

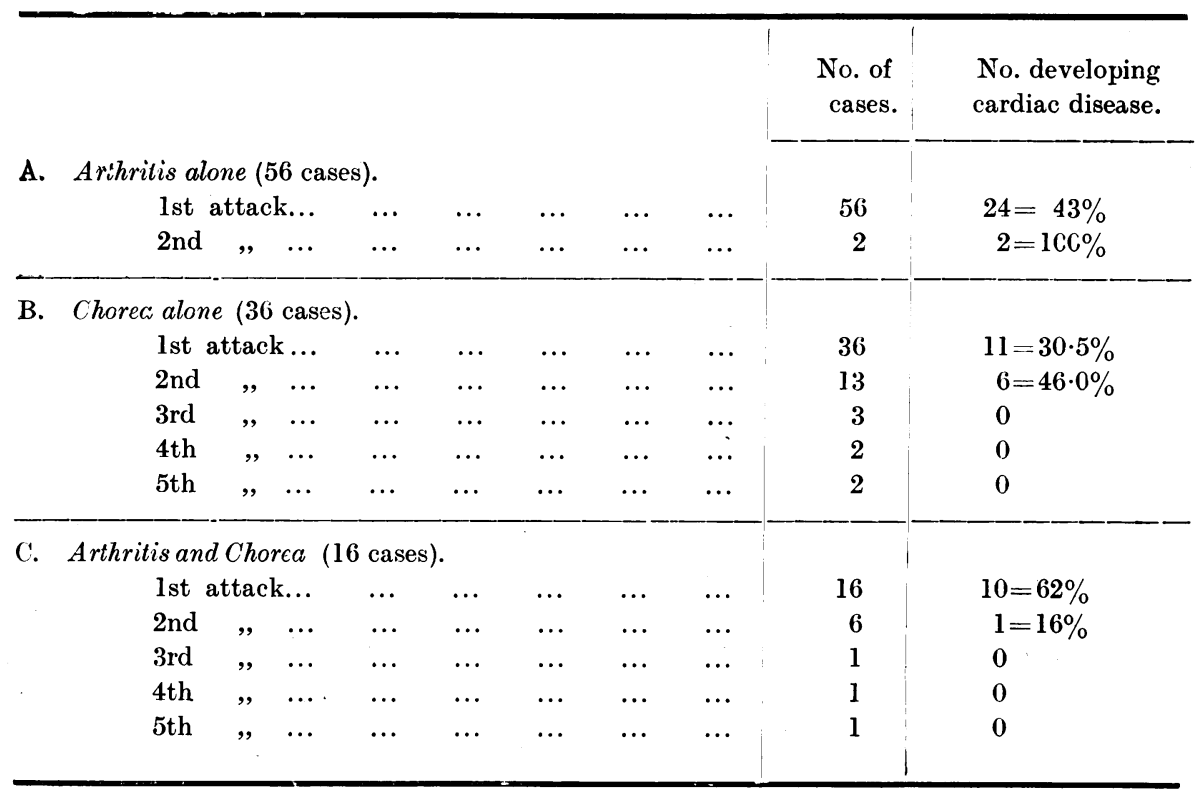


From the above analysis it is seen that in no case in which the time of appearance of the cardiac involvement was known did this complication develop after the 2nd attack. This was so not only in those patients with chorea or arthritis alone, but also when they suffered from both chorea and arthritis. In this last group the onset of heart disease was related, as previously mentioned, to the rheumatic manifestation in its true sequence, whether such was chorea or arthritis. In the cases with arthritis or chorea there was a greater incidence of cardiac disease during the 2nd attack than during the first, in fact every case of pure arthritis which escaped carditis during the 1st attack succumbed during the second. In the cases with both arthritis and chorea there was, on the other hand, a greater incidence during the 1st than during the 2nd manifestation of the disease. Without doubt the number of cases of arthritis passing through a second attack is too small to warrant serious consideration, but the other groups of cases are sufficiently large to justify at least tentative conclusions. It would seem, therefore, so far as the evidence of our material goes, that if carditis is to result it will do so during the lst or 2nd attacks of arthritis or chorea, and on the whole is more likely to develop during the 2 nd than during the 1st, but seldom if ever after an individual has passed through two attacks with the heart unscathed. This relationship of carditis to the first or at least the early attucks oi arthritis or chorea, in addition to having a comforting prognostic significance, focusses attention on the importance of prophylaxis. The chief point, however, in connection with these findings, so far as the present discussion is concerned, is that if we wish to draw deductions regarding the effect of tonsillectomy on the prevention of cardiac disease only those cases which were tonsillectomized before the onset of the disease, or before the 2 nd attack of chorea or arthritis, and of course with the heart still intact, can be legitimately contrasted with the non-tonsillectomized examples. This comparison is shown in the following table (Table 4). The non-tonsillectomized cases are considered not only as a whole but also according to whether tonsillectomy was or was not considered necessary.

From Table 4 it is seen that of the cases with chorea alone the least incidence of cardiac disease was in those who were the subjects of a preliminary tonsillectomy. This apparent benefit of tonsillectomy is, however, counter-balanced by the fact that there occurred a greater incidence among those tonsillectomized early in the course of the disease than among those never tonsillectomized.

In the cases with arthritis alone the one child who was operated upon before the occurrence of any rheumatic infection escaped altogether affection of the heart, and there was also a very low incidence in those tonsillectomized early in the disease. Of the non-tonsillectomized cases, however, the less incidence occurred in those requiring tonsillectomy, so that the highest incidence of cardiac disease among the children with apparently normal throats is the most noteworthy feature of this group.

Of those children who suffered from both arthritis and chorea a greater incidence of cardiac disease was obtained in the tonsillectomized, and among the non-tonsillectomized the frequency of cardiac involvement apparently bore no relationship to the need of the operation. 
TABLE 4.

Showing EFFECT of TONSILleCtomy on DeVelopment of CARdiac disease.

\begin{tabular}{|c|c|c|c|c|}
\hline \multirow[b]{2}{*}{$\begin{array}{l}\text { A.-Cases with } \\
\text { chorea alone. }\end{array}$} & & $\begin{array}{c}\text { No. of } \\
\text { cases }\end{array}$ & $\begin{array}{l}\text { No. with } \\
\text { cardiac } \\
\text { disease }\end{array}$ & $\begin{array}{l}\% \text { with } \\
\text { cardiac } \\
\text { disease }\end{array}$ \\
\hline & $\begin{array}{l}\text { Non-tonsillectomized. } \\
\begin{aligned} & \text { (a) Requiring tonsillectomy ... } \ldots \\
& \text { (b) Not requiring tonsillectomy } \ldots \\
& \text { Total }\end{aligned} \\
\text { Tonsillectomized : before infection } \ldots \\
\qquad, \quad \text { : before 2nd attack ... }\end{array}$ & $\begin{array}{rr}9 & \\
10 & \\
& 19 \\
6 & \\
6 & \end{array}$ & $\begin{array}{ll}3 & \\
2 & \\
& 5 \\
1 & \\
3 & \end{array}$ & $\begin{array}{l}33 \\
20 \\
\\
16 \cdot 6 \\
50\end{array}$ \\
\hline $\begin{array}{l}\text { B.-Cases with } \\
\text { arthritis alone. }\end{array}$ & $\begin{array}{l}\text { Non-tonsillectomized } \\
\begin{aligned} & \text { (a) Requiring tonsillectomy ... } \ldots \\
& \text { (b) Not requiring tonsillectomy } \ldots \\
& \text { Total }\end{aligned} \\
\text { Tonsillectomized : before infection } \ldots \\
\qquad, \quad \text { : before 2nd attack }\end{array}$ & $\begin{array}{ll}30 & \\
25 & \\
& 55 \\
1 & \\
8 & \end{array}$ & $\begin{array}{cc}16 & \\
16 & \\
& 32 \\
0 & \\
1 & \end{array}$ & $\begin{array}{rr}53 & \\
64 & \\
& 58 \\
0 & \\
12 & \end{array}$ \\
\hline $\begin{array}{l}\text { C.-Cases with } \\
\text { chorea and } \\
\text { arthritis. }\end{array}$ & $\begin{array}{l}\text { Non-tonsillectomized. } \\
\begin{array}{r}\text { (a) Requiring tonsillectomy ... } \\
\text { (b) Not requiring tonsillectomy } \ldots \\
\text { Total } \\
\text { Tonsillectomized : before infection } \ldots \\
\qquad, \quad \text { : before 2nd attack ... }\end{array}\end{array}$ & $\begin{array}{ll}7 & \\
9 & \\
& 16 \\
1 & \\
3 & \end{array}$ & $\begin{array}{l}4 \\
5 \\
1 \\
2\end{array}$ & $\begin{array}{rr}57 & \\
5 \tilde{5} & \\
& 56 \\
100 & \\
66 & \end{array}$ \\
\hline D. -All cases $\ldots$ & $\begin{array}{l}\text { Non-tonsillectomized. } \\
\begin{array}{r}\text { (a) Requiring tonsillectomy ... } \\
\text { (b) Not requiring tonsillectomy }\end{array} \\
\text { Total } \\
\qquad \begin{array}{l}\text { Tonsillectomized : before infection } \ldots \\
\quad \text { : before } 2 \text { nd attack ... }\end{array}\end{array}$ & $\begin{array}{rr}52 & \\
46 & \\
& 98 \\
8 & \\
15 & \end{array}$ & $\begin{array}{rr}28 & \\
25 & \\
& 53 \\
3 & \\
5 & \end{array}$ & $\begin{array}{ll}53 \cdot 8 & \\
54 & \\
& 54 \\
37 & \\
33 & \end{array}$ \\
\hline
\end{tabular}

When all the cases are grouped together, irrespective of whether they suffered from arthritis or chorea, a less incidence of cardiac disease is seen among the tonsillectomized but of the non-tonsillectomized there was no difference when classified according to evidence of disease of the tonsils.

The findings then are so various and contradictory that it is very difficult, in fact impossible to draw any conclusions. Some of the groups of course are too small to warrant any consideration at all, and it is possible that with a much larger series of cases some more definite evidence, one way or the other might be forthcoming. The apparent benefit of tonsillectomy in the case of those patients who suffered from arthritis alone is negatived by the findings in those suffering from chorea, as also by the greater susceptibility of those requiring tonsillectomy among the non-tonsillectomized group. The possible beneficial effect of tonsillectomy in preventing cardiac disease in the arthritic group is, however, in keeping with the previously mentioned possible prophylactic effect on arthritis of a preliminary tonsillectomy, but the whole evidence is so slight that one hesitates to formulate any generalisation for or against this line of attack. 


\section{EHFeCT OF TONSILLECTOMY ON THE PROGRESS OF THE CARDIAC CONDITION.}

Even although the operation of tonsillectomy has no marked effect in hindering the development of disease of the heart it might be that it would have some influence on the progress of the disease, and the analysis of our material relative to this point is given below (Tables 5,6 and 7 ).

In our work at the cardiac clinic or rheumatism supervision centre it has been the custom to classify the cases according to the presence or absence of a cardiac lesion and according to the severity of this lesion when present, thus:-class P, (potential cardiac disease) cases with no cardiac disease; class $A$, cases with a transient murmur during the acute phase ; class $B$, cases with signs but no symptoms of heart disease; class $\mathrm{C}$, cases with signs and moderate symptoms of heart disease; class $\mathrm{D}$, cases with signs and marked symptoms of heart disease. For a fuller appreciation of the progress of the cardiac condition during the period under consideration the classification on dismissal from hospital (1924) and that on the occasion of the last examination (1928), as well as the direction in which the change of class occurred, are detailed in the Tables (Nos. 5, 6 and 7). As before, the cases have been grouped according to whether there was only chorea, only arthritis, or both arthritis and chorea in the one individual.

TABLE 5.

Showing PRogress of CARDIAC CONDITION IN TONSILleCtomized AND NON-TONSILleCtomized CHILDREN.

Cases with chorea alone.

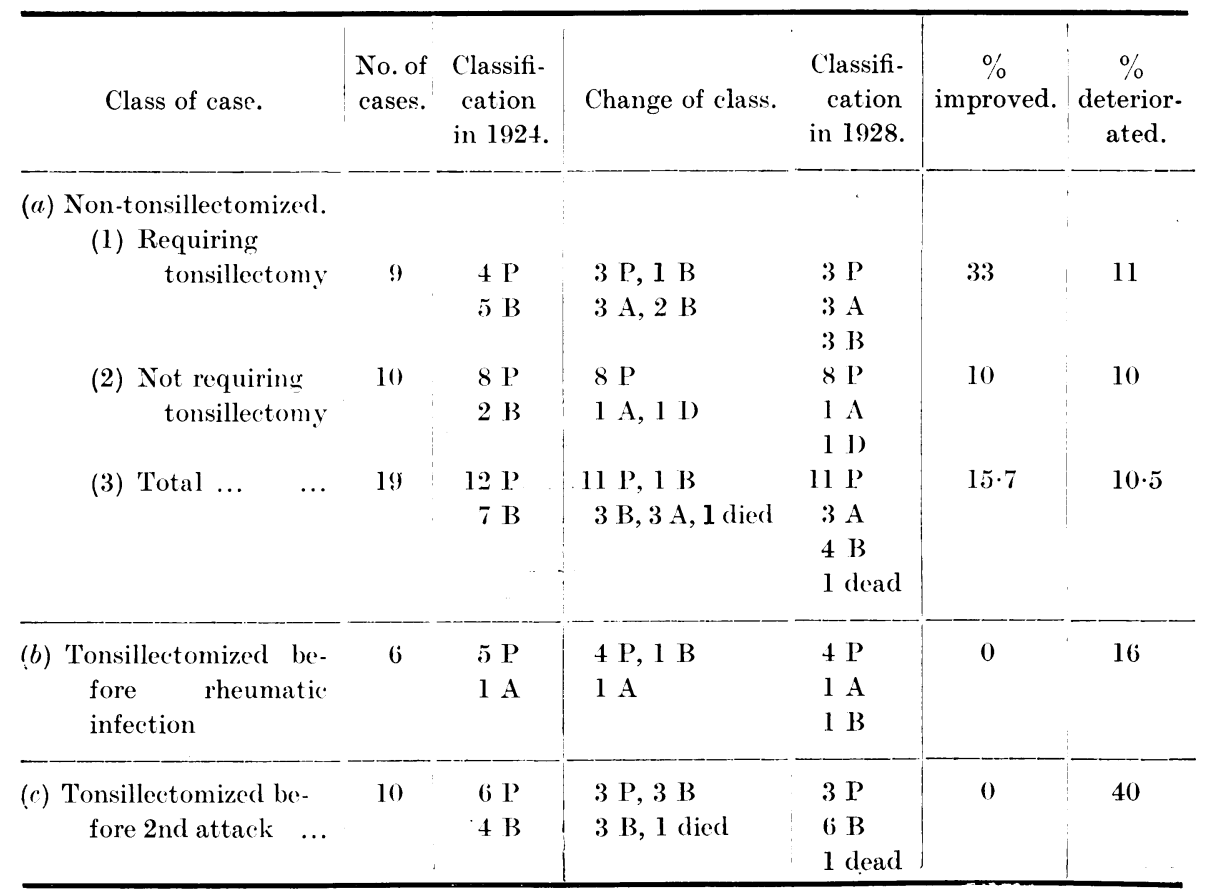


TABLE 6.

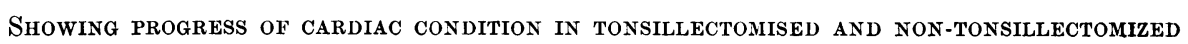
CHILDREN.

Cases with arthritis alone.

\begin{tabular}{|c|c|c|c|c|c|c|}
\hline Class of Case. & $\begin{array}{l}\text { No. of } \\
\text { cases. }\end{array}$ & $\begin{array}{l}\text { Classifi- } \\
\text { cation } \\
\text { in } 1924 .\end{array}$ & Change of Class. & $\begin{array}{l}\text { Classifi- } \\
\text { cation } \\
\text { in } 1928 .\end{array}$ & $\begin{array}{c}\% \\
\text { improved. }\end{array}$ & $\begin{array}{c}\% \\
\text { deterior- } \\
\text { ated. }\end{array}$ \\
\hline $\begin{array}{l}\text { (a) Non-tonsillectomized } \\
\text { (1) Requiring } \\
\text { tonsillectomy } \\
\text { (2) Not requiring } \\
\text { tonsillectomy } \\
\text { (3) Total ... }\end{array}$ & 25 & $\begin{array}{rl}6 & \mathrm{P} \\
5 & \mathrm{~A} \\
12 & \mathrm{~B} \\
1 & \mathrm{C} \\
6 \mathrm{D} \\
5 \mathrm{P} \\
5 \mathrm{~A} \\
6 \mathrm{~B} \\
3 \mathrm{C} \\
6 \mathrm{D} \\
11 \mathrm{P} \\
10 \mathrm{~A} \\
18 \mathrm{~B} \\
4 \mathrm{C} \\
12 \mathrm{D}\end{array}$ & $\begin{array}{l}5 \mathrm{P}, 1 \mathrm{~B} \\
5 \mathrm{~A} \\
7 \mathrm{~B}, 4 \mathrm{~A}, 1 \text { died } \\
1 \mathrm{died} \\
6 \mathrm{died} \\
5 \mathrm{P} \\
4 \mathrm{~A}, 1 \mathrm{~B} \\
6 \mathrm{~B} \\
1 \mathrm{~B}, 1 \mathrm{C}, 1 \text { died } \\
4 \mathrm{died}, 2 \mathrm{~B} \\
10 \mathrm{P}, 1 \mathrm{~B} \\
9 \mathrm{~A}, 1 \mathrm{~B} \\
4 \mathrm{~A}, 13 \mathrm{~B}, 1 \text { died } \\
1 \mathrm{C}, 1 \mathrm{~B}, 2 \text { died } \\
10 \mathrm{D}, 2 \mathrm{~B}\end{array}$ & $\begin{array}{rl}5 & \mathrm{P} \\
9 & \mathrm{~A} \\
8 \mathrm{~B} \\
8 \text { dead } \\
5 \mathrm{P} \\
4 \mathrm{~A} \\
10 \mathrm{~B} \\
1 \mathrm{C} \\
5 \text { dead } \\
10 \mathrm{P} \\
13 \mathrm{~A} \\
18 \mathrm{~B} \\
1 \mathrm{C} \\
13 \text { dead }\end{array}$ & 12 & 25 \\
\hline $\begin{array}{l}\text { (b) Tonsillectomized be- } \\
\text { fore infection }\end{array}$ & 1 & $1 \mathrm{P}$ & $1 \mathrm{P}$ & $1 \mathrm{P}$ & 0 & 0 \\
\hline $\begin{array}{l}\text { (c) Tonsillectomized be- } \\
\text { fore } 2 \text { nd attack }\end{array}$ & 14 & $\begin{array}{ll}3 & \mathrm{P} \\
4 & \mathrm{~A} \\
6 & \mathrm{~B} \\
1 & \mathrm{C}\end{array}$ & $\begin{array}{l}3 \mathrm{P} \\
3 \mathrm{~A}, 1 \mathrm{~B} \\
5 \mathrm{~B}, 1 \mathrm{~A} \\
1 \mathrm{~B}\end{array}$ & $\begin{array}{ll}3 & \mathrm{P} \\
4 & \mathrm{~A} \\
7 & \mathrm{~B}\end{array}$ & 14 & 7 \\
\hline
\end{tabular}

From the above analysis it is seen that of the cases with chorea alone the smallest proportion of cases deteriorated and the largest proportion improved among the non-tonsillectomized, and among these latter more satisfactory progress was observed in the case of those who required tonsillectomy. Of the cases with arthritis alone, on the other hand, if we except the small group of 2 the subject of a preliminary tonsillectomy, it was the non-tonsillectomized which showed the smallest proportion of improvement but the highest proportion of deterioration so that once more we see some slight evidence of the value of tonsillectomy when arthritis is the primary rheumatic manifestation. Of the cases with both chorea and arthritis those tonsillectomized showed the greatest proportion of deterioration and there was little difference in the incidence of improvement in the tonsillectomized and non-tonsillectomized. Thus on the whole we cannot discover any marked evidence of the beneficial effect of tonsillectomy. 
TABLE 7.

SHOWING PROGRESS OF CARDIAC CONDITION IN TONSILLECTOMIZED AND NON-TONSILLECTOMIZED CHILDREN.

CASES OF aRthritis AND ChOREA.

\begin{tabular}{|c|c|c|c|c|c|c|}
\hline Class of case. & $\begin{array}{l}\text { No. of } \\
\text { cases. }\end{array}$ & $\begin{array}{l}\text { Classifi- } \\
\text { cation } \\
\text { in } 1924 .\end{array}$ & Change of class. & $\begin{array}{c}\text { Classifi } \\
\text { cation } \\
\text { in } 1928 .\end{array}$ & $\begin{array}{c}\% \\
\text { improved. }\end{array}$ & $\begin{array}{l}\% \\
\text { deterior- } \\
\text { ated. }\end{array}$ \\
\hline (a) Non-tonsillectomized & 13 & $\begin{array}{l}5 \mathrm{P} \\
8 \mathrm{~B}\end{array}$ & $\begin{array}{l}4 \mathrm{P}, 1 \mathrm{~B} \\
3 \mathrm{~A}, 3 \mathrm{~B} \\
1 \mathrm{C}, 1 \mathrm{died}\end{array}$ & $\begin{array}{l}4 \mathrm{P} \\
3 \mathrm{~A} \\
4 \mathrm{~B} \\
1 \mathrm{C} \\
1 \text { died }\end{array}$ & 23 & 23 \\
\hline $\begin{array}{l}\text { (b) Tonsillectomized be- } \\
\text { fore rheumatic in- } \\
\text { fection }\end{array}$ & 1 & $\mathbf{P}$ & B & B & 0 & 100 \\
\hline $\begin{array}{l}\text { (c) Tonsillectomized be- } \\
\text { fore } 2 \text { nd attack }\end{array}$ & 7 & $\begin{array}{l}3 \mathrm{P} \\
4 \mathrm{~B}\end{array}$ & $\begin{array}{l}1 \mathrm{P}, 2 \mathrm{~B} \\
2 \mathrm{~A}, 1 \mathrm{~B} \\
1 \mathrm{C}\end{array}$ & $\begin{array}{ll}1 & \mathrm{P} \\
2 & \mathrm{~A} \\
3 & \mathrm{~B} \\
1 & \mathrm{C}\end{array}$ & 28 & 43 \\
\hline
\end{tabular}

\section{Discussion.}

A survey of the whole material above submitted supplies little evidence that tonsillectomy exerts any great effect on the development or course of the rheumatic infection. In view of some of the facts elicited, e.g. the small number of cases who develop arthritis after a preliminary tonsillectomy, the small proportion of cases of arthritis who have been tonsillectomized early during the course of the infection and who develop cardiac complications, and the tendency in these same cases for the cardiac condition to improve, it would seem that in the examples of the rheumatic infection characterized by arthritis rather than by chorea the operation may have both a prophylactic and a therapeutic effect. This possible beneficial effect assumes an increased importance when we remember that of all cases of rheumatic infection the majority are of the arthritic type, and that it is this type which is responsible for the greatest proportion of cardiac disease. The evidence, however, of the benefit accruing from the procedure is very slight and is counterbalanced by the less grave effects of the infection in those children not operated upon, but who apparently require it, than in those who are not the subjects of disease of the tonsils. In any case, if the operation is to be of any avail, so far as prevention of cardiac disease is concerned, it must be done before the onset of a second attack of arthritis as the heart would seem to be invariably implicated during either the 1st or second manifestation. In the case of those examples of the rheumatic infection characterized by chorea tonsillectomy would not seem to have any effect at all. This varying reaction to the effect of tonsillcctomy 
in the case of chorea and arthritis, as well as the fact that cardiac disease complicates much more frequently arthritis than chorea, raises the much discussed question of what proportion of examples of Sydenham's chorea are rheumatic in origin and suggests the possibility of a different strain of the infective agent in these two types of the disease.

We admit of course that our numbers are small, and it is quite possible that a larger series of cases might reveal more definite evidence one way or the other. The communication has the failings of its very virtues since by being the record of personal experiences in one clinic over a comparatively prolonged period the numbers are necessarily small.

\section{Conclusions.}

1. A preliminary tonsillectomy may possibly render an individual less susceptible to rheumatic arthritis but not to chorea.

2. A preliminary tonsillectomy or one performed early during the course of the infection may possibly, in the case of arthritis, render the heart less liable to be attacked but not so in the case of chorea.

3. As, however, cardiac complications usually ensue during the first or second rheumatic manifestations the operation to be prophylactic must be performed before the second attack.

4. Tonsillectomy in the case of carditis following arthritis seems to have a beneficial effect on the progress of the disease but not so in carditis following chorea.

5. The evidence in favour of the above beneficial effect of tonsillectomy in the case of rheumatic manifestations characterised by arthritis is, however, very slight.

6. Tho varying behaviour in response to tonsillectomy of examples of the rheumatic infection characterized by chorea and by arthritis suggests the possibility of a different strain of the infective agent in these two types of the disease.

\section{REFEREN(TS.}

1. Medical Research ('ouncil, Special Report Series, London, No. 114, 1927.

2. Miller, R., Brit. Med. J., London, 1926, ii. (Supp.), 5.

3. Kaiser, A. D., J. Am. Med. Assoc., ('hic., 1927, LXXXIX., 2239. 